\title{
IMPROVING RELIABILITY OF PARTS OF MOUNTED MOWER ACCORDING TO MONITORING RESULTS BY FATIGUE GAUGES FROM TIN FOIL
}

\author{
Sergey Tyutrin \\ Kurgan State University, Russia \\ kgu_sm@rambler.ru
}

\begin{abstract}
Problems of increase of reliability and reduction of idle time of agricultural machinery are considered. To prevent fatigue failure of the most loaded parts, it is proposed to monitor them using fatigue gauges made of tin foil. Such gauges have low cost and quickly react to relatively low stresses. Fatigue gauges made of tin foil can be visually monitored using a microscope at magnification of 100 or less. Results of reliability improvement of parts of a mounted mower "KC-2,1" according to the monitoring data by fatigue gages from tin foil are described. These results are: durability-increasing technology of the knife head of the mower; technology of the connecting rod strength increasing. The probability of non-destruction of the knife head increased to $99.5 \%$. The assurance factor of the connecting rod after repair was increased by 2.6 times. The technology of using tin foil as a fatigue gauge for measuring cyclic stresses is described. The scheme of the stand for calibration tests of fatigue gauges is presented. A low-cost method of carrying out calibration tests is described. The calibration specimen is shown. The calibration curve of the fatigue gauge and photos of its surface during the inspection are presented. It is noted that the sensitivity of fatigue gauges made of tin foil is much higher than that of fatigue gauges made of copper or aluminum. Tin foil fatigue gauges are effective helpers in improving the profitability of agricultural production and attractiveness of rural areas.
\end{abstract}

Keywords: reliability, fatigue gauge, monitoring.

\section{Introduction}

In order to make rural areas attractive for life and work, high profitability of agricultural production is necessary. One of the factors that increase the profitability of work in crop production is reduction in the number of breakdowns and downtime of agricultural machinery. To prevent fatigue failure of the most loaded parts, it is proposed to monitor them using fatigue gauges made of tin foil.

In comparison with strain sensors, the use of fatigue gauges does not require expensive electrical and electronic equipment. A fatigue gauge is a fragment of foil that reads, summarizes, stores and indicates data about the cyclic stress parameters acted on the part surface.

For the first time in the world $\mathrm{H}$. Okubo proposed to use galvanic copper foil as a means of measuring cyclic stresses, acting on the surface of machine parts [1]. The works [2;3] describe the results of measurements using copper fatigue gauges of the maximum stress values arising in the friction discs of the variator, in the engine crankshaft, in the valve of the refrigerator's compressor, in helical gears.

In the process of measuring stresses in friction discs, 5 million loading cycles were required. In the basic version of the design, the value of the stress amplitude was $240 \mathrm{MPa}$. After rounding the sharp corners, the stress amplitude dropped to $180 \mathrm{MPa}$ [2].

In the process of measuring stresses in the crankshaft of the engine, 5 million loading cycles were required. In the basic version of the design, the value of the stress amplitude was $225 \mathrm{MPa}$. After increasing the radius of the concentrator the stress amplitude decreased by 2 times [2].

In the process of measuring stresses in the valve of the refrigerator's compressor, 1 million loading cycles were required. In the basic version of the design, the value of the stress amplitude was $530 \mathrm{MPa}$. After improving the shape of the valve the stress amplitude decreased to $410 \mathrm{MPa}$ [2].

In the process of measuring stresses in helical gears, 3 million loading cycles were required. The values of stress amplitudes found at different points ranged from 201.3 to $537.9 \mathrm{MPa}$ [3].

With help of the electroplating method [1;2] H. Okubo found the values of the stress concentration factor for slot grooves. These results were included in the directory [4].

In work [5] it was for the first time offered to use fatigue gauges made of aluminum foil as means of stress measuring. Aluminum foil fatigue gauges are more sensitive than copper gauges. Calibration dependences of aluminum fatigue gauges for specimens made of high-strength steels are presented in [6]. It is found that the response of such a gauge at the stress amplitude of $208.9 \mathrm{MPa}$ will require 10,000 cycles. If the stress amplitude is $109.3 \mathrm{MPa}$, the gauge's reaction appears after 100,000 cycles. 
If the stress amplitude is $73.7 \mathrm{MPa}$, the gauge's reaction appears after 1 million cycles. Fatigue gauges made of aluminum foil have been successfully used in the study of parts or specimens that have experienced cyclic stresses [6-8] or cyclic straines $[9 ; 10]$ with large amplitudes.

In crop production there are many parts of agricultural machines, which are destroyed under relatively small operational stresses. These are frames, housings, shafts and some others. To ensure the efficiency of control, when working in such conditions, fatigue gauges of high sensitivity are needed.

\section{Materials and methods}

The paper [11] describes the results of the forecast, according to which the fatigue gauges made of tin foil should have high sensitivity. Based on this forecast, experimental studies of fatigue gauges from tin were carried out.

Tin foil of industrial production was used. It was manufactured according to the Russian standard GOST 18394-73. Foil thickness was $20 \mu \mathrm{m}$. According to this standard, tin foil is made of an alloy of tin with antimony, in which antimony is $1.9-3.1 \%$. In addition, this foil was annealed at the temperature of $200-203^{\circ} \mathrm{C}$ for 10 hours.

The high sensitivity of the fatigue gauges made of tin foil was confirmed, when the problem of low durability of the "KC-2,1" mower was considered. Due to the unfavourable weather forecast, mowing of grasses was carried out at high speed. In such conditions, the knife head of the mower was failed after exploitation for 10 hours or less (Fig. 1). Inspection of the gauges confirmed their high damage near the zone of the fatigue fracture. In addition, the gauges located on the junction of the wall and base part of the knife head also had high damages: these gauges had a long crack. In order to improve the reliability of the knife head, its thickness in hazardous zones has been increased by welding deposition (Fig. 2). In addition, the values of fillet radiuses in the corners and hollow chamfers have been increased. To verify the effectiveness of this solution, comparative stand tests of the basic and new variants of the knife head were carried out [12].

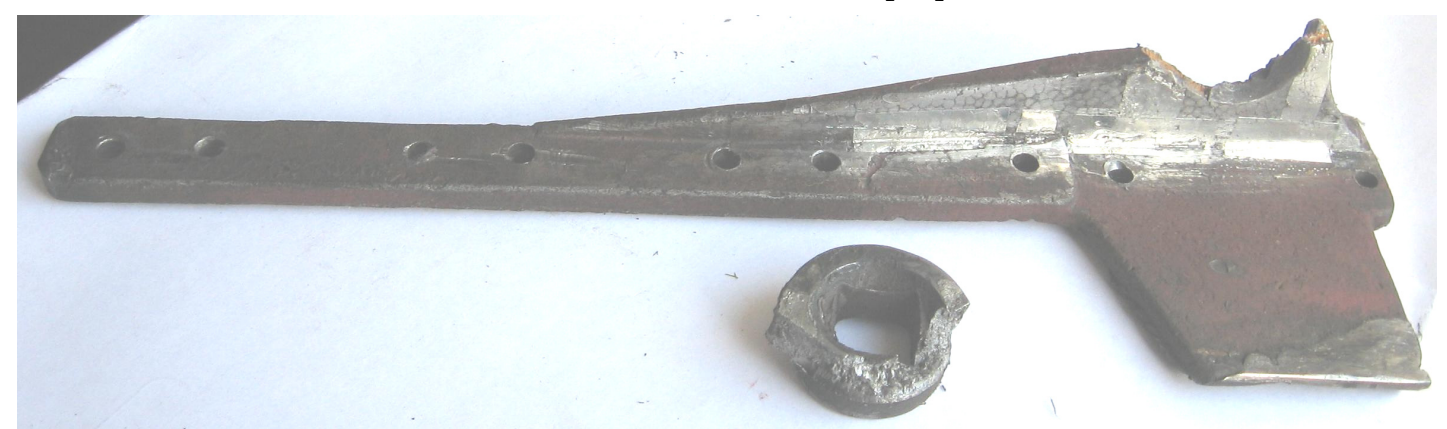

Fig. 1. Knife head with fatigue gauges after failure

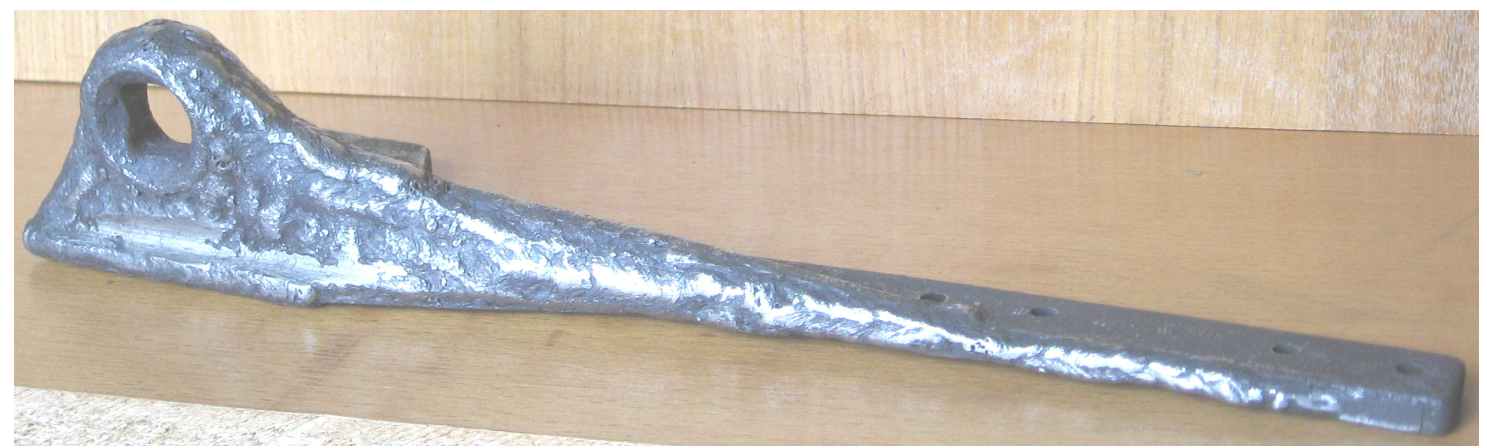

Fig. 2. Knife head after welding deposition

First of all, the calibration dependence for tin foil fatigue gauges was determined. For this purpose, a test specimen was made from the new knife head (Fig. 3). The knife heads are made of steel “30Л” or “35Л".

Steels "30Л" and "35Л" are non-alloy steels for castings. According to the Russian standard GOST 977-88, the chemical composition of steel "30Л" is (weight \%): 0.27-0.35 C, 0.2-0.52 Si, 0.45- 
$0.9 \mathrm{Mn}$, up to $0.06 \mathrm{~S}$ and up to $0.06 \mathrm{P}$. And the mechanical properties of this steel are: tensile strength $471 \mathrm{MPa}$, yield strength $255 \mathrm{MPa}$, minimum elongation $17 \%$, minimum reduction in area $35 \%$.

According to the GOST 977-88, the chemical composition of steel "35Л" is (weight \%): $0.32-0.40$ $\mathrm{C}, 0.2-0.52 \mathrm{Si}, 0.45-0.9 \mathrm{Mn}$, up to $0.06 \mathrm{~S}$ and up to $0.06 \mathrm{P}$. And the mechanical properties of this steel are: tensile strength $491 \mathrm{MPa}$, yield strength $275 \mathrm{MPa}$, minimum elongation $15 \%$, minimum reduction in area $25 \%$.

The fatigue gauge has been pasted on the test specimen. Before testing, the fatigue gauge surface was thoroughly polished. The surface view of the fatigue gauge obtained using magnification of 98 is presented in Fig. 4a.

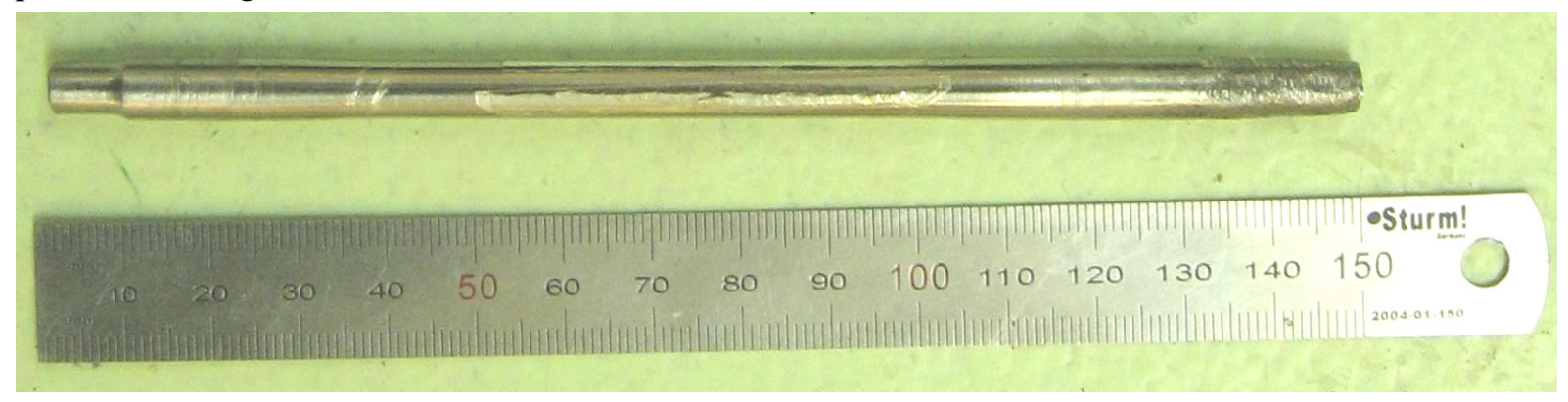

Fig. 3. Calibrating specimen with fatigue gauge
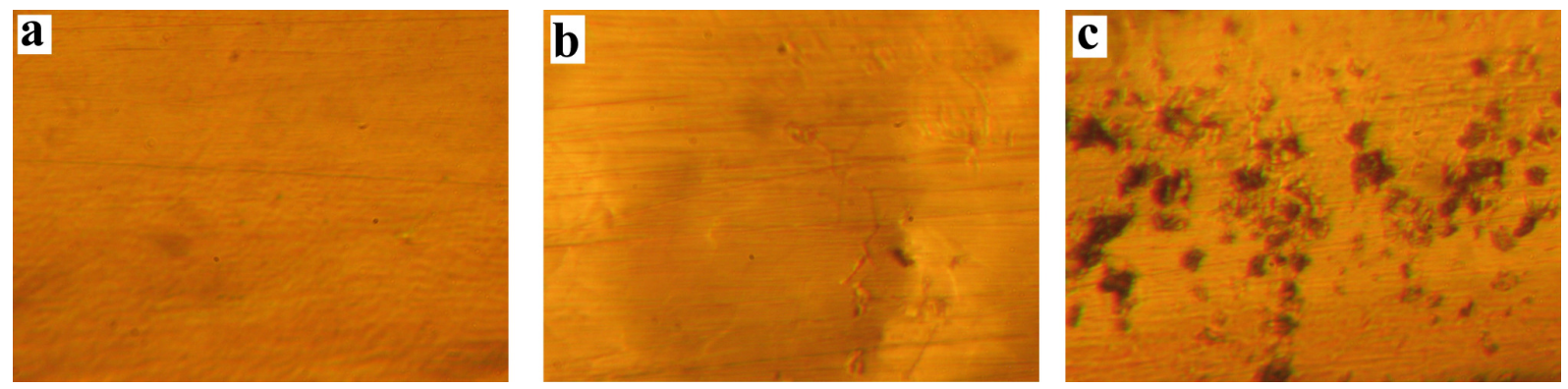

Fig. 4. Surface views of fatigue gauge: $a$ - before the test; $b$ - with the first visible damages; $c$ - with strong damages

Figure 5 shows the used scheme for calibration of fatigue gauges. Cyclic stresses were created by rotating a specimen bent by a cantilever applied load. This scheme of fatigue testing is widely known [13]. For its implementation, a lathe was used. The test specimen was secured in its clamping chuck. The frequency of rotation was $1.67 \mathrm{~Hz}$. The number of stress cycles was fixed with help of a mechanical counter.

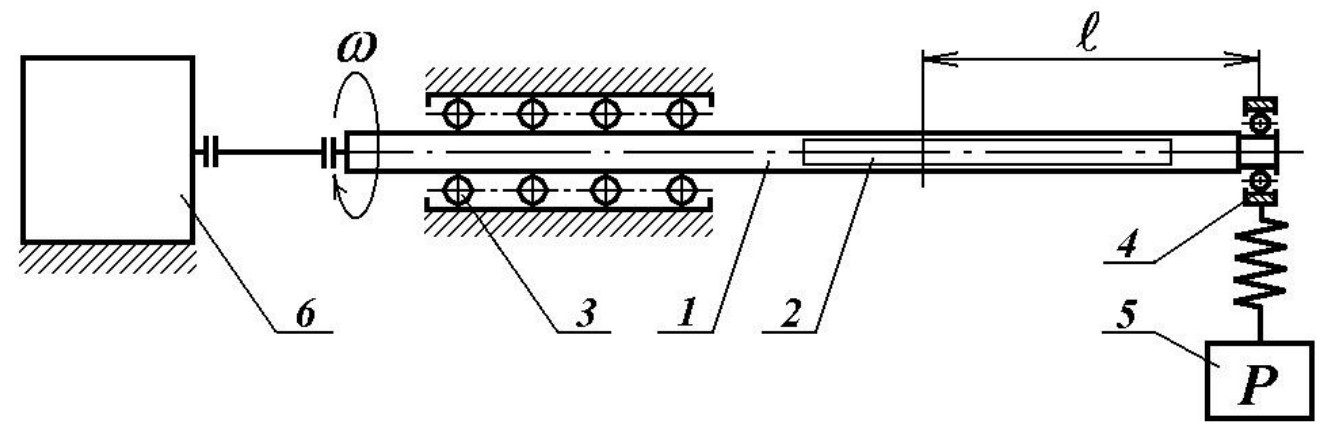

Fig. 5. Scheme for calibration of fatigue gauges: 1 - test specimen; 2 - fatigue gauge; 3 - carriage support bearing; 4 - rolling bearing; 5 - load; 6 - counter of stress cycles

During the test, the lathe was periodically stopped and inspections of the surface of the fatigue gauge were carried out. The appearance of the first changes in the gauge surface, such as dislocations, distortions, slip lines and other fatigue damages, was fixed. The view of the first visible fatigue damages on the gauge's surface detected using magnification of 98 is presented in Fig. $4 \mathrm{~b}$. The 
distance $\ell$ from the line of gravity of the load $P$ to the first detected dislocations on the surface of the fatigue gauge was measured.

It should be noted that it is quite convenient to find the position of newly appeared dislocations on the surface of the fatigue gauge: they are located at the boundary, beyond which the damage intensity in the gauge increases (Fig. 4c). [14]:

The amplitude of cyclic stresses on the specimen surface was calculated in MPa by the formula

$$
\sigma_{a}=\frac{32 P \ell}{\pi d^{3}},
$$

where $P$ - weight of the load together with its suspension member and rolling bearing, $\mathrm{N}$;

$\ell$ - distance from the line of gravity of the load $P$ to the inspected cross-section of the specimen, mm;

$d$-diameter of the inspected cross-section of the specimen, $\mathrm{mm}$.

\section{Results and discussion}

Fig. 6 shows the calibrating dependence, which was obtained. With help of this dependence the maximum stresses of the basic and new variants of the knife head were determined [12]. Fig. 7 shows the scheme of the testing stand, which was used: alternate lifting and lowering of loads with a weight of $2 P$ creates the alternating bending moment with the amplitude of $P h$. It was found that due to the welding deposition, the values of the arising maximum stresses were reduced by 3.1 times. The probability of non-destruction of the knife head increased to $99.5 \%$. The knife head of increased strength worked for 3 seasons and remained suitable for further operation.

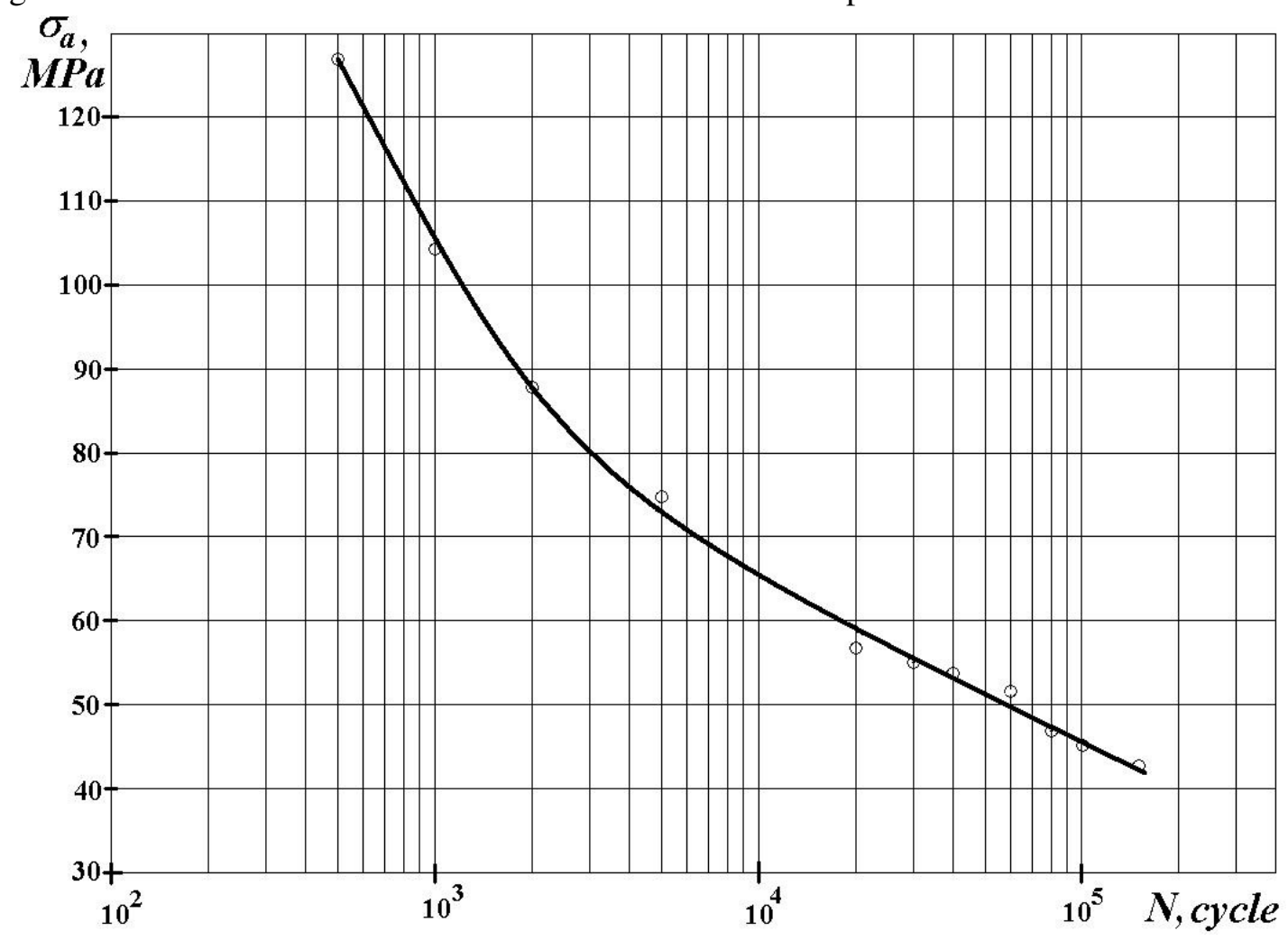

Fig. 6. Calibrating dependence for fatigue gauge made of tin foil: $\sigma_{a}$ - amplitude of cyclic stresses on the specimen surface; $N$ - number of stress cycles before detection of the first dislocations on the gauge surface 


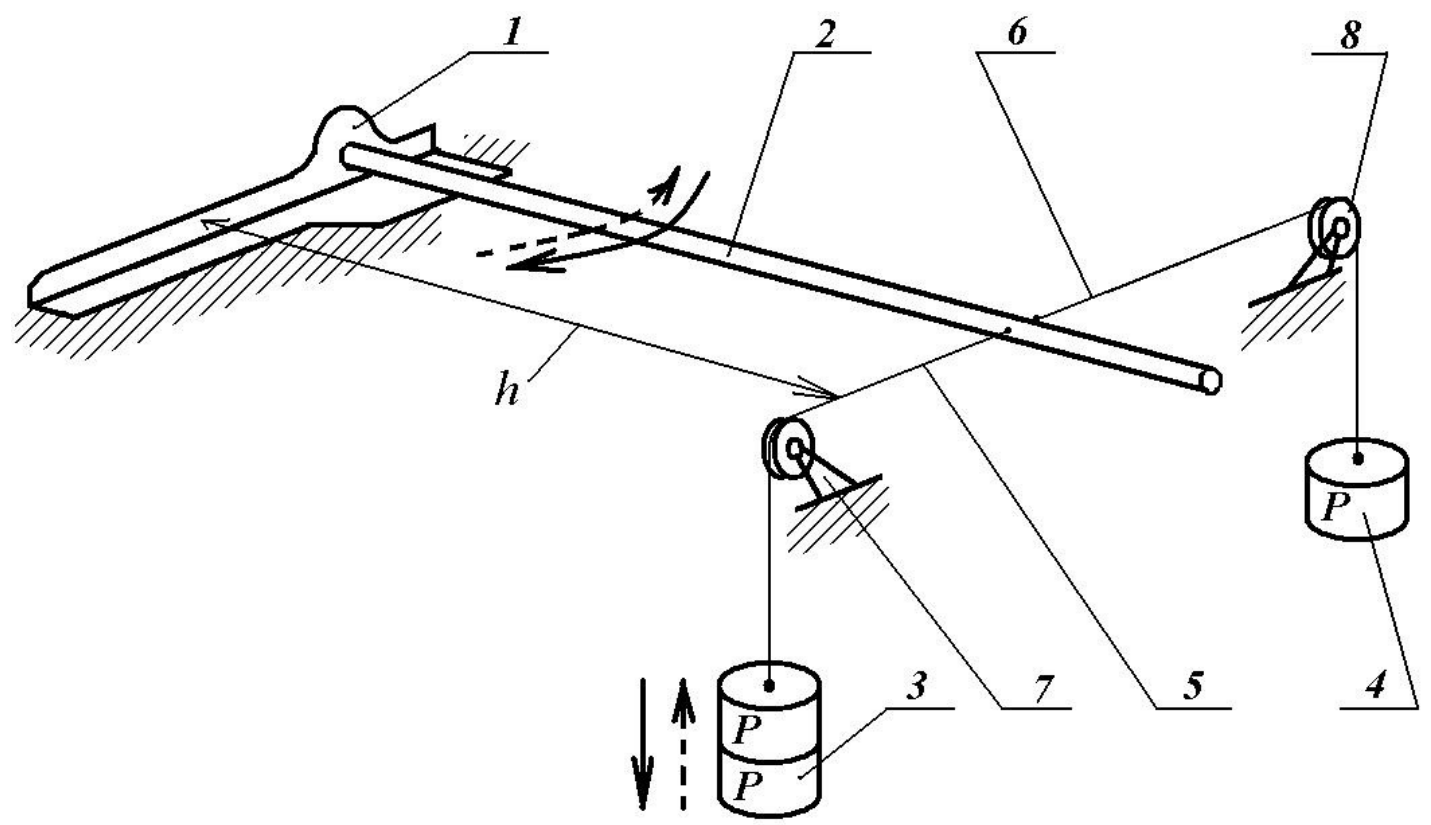

Fig. 7. Scheme of testing stand for stress evaluation in knife head: 1 - knife head; 2 - lever; 3, 4- loads; 5, 6- thin steel cables; 7, 8 - guide rollers

Another low durability part of the mower "KC-2,1" is the connecting rod. For its control during exploitation the fatigue gauges made of tin foil were used. With help of these gauges, a zone with a high concentration of stresses was detected. This zone was located at a distance of $43 \mathrm{~mm}$ from the end of the connecting rod on the side of the threaded bushing. Usually it is in this place that the connecting rod is destroyed (Fig. 8).

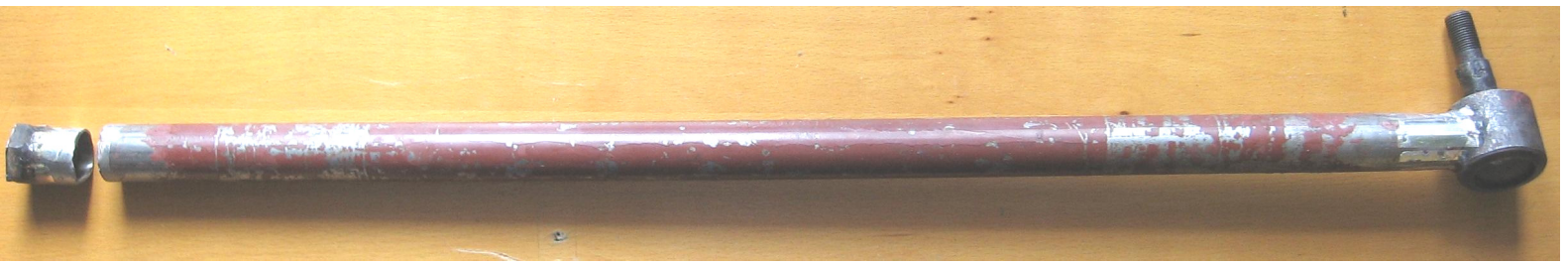

Fig. 8. Connecting rod with fatigue gauges after failure

The study of the destroyed parts of the connecting rod together with the analysis of the gauge damages allowed to find the cause of the failure. This reason was the excessive thinning of the connecting rod pipe during boring for installation of the threaded bushing. Moreover, this boring ends with a fillet with a small radius of rounding. It was proposed to perform welding in the place of destruction during the repair process, as well as to strengthen the structure by welding an additional outer sleeve (Fig. 9). The performed calculations have shown that the assurance factor of the connecting rod after repair was increased by 2.6 times [15].

$\mathbf{a}$

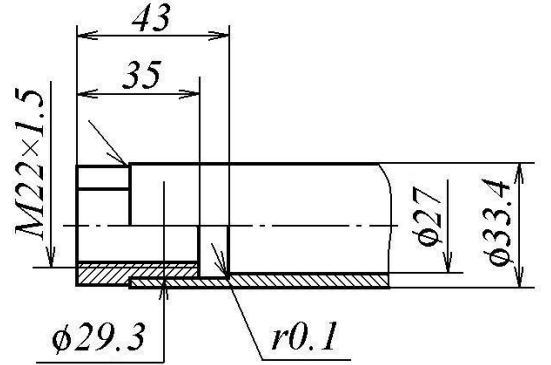

b

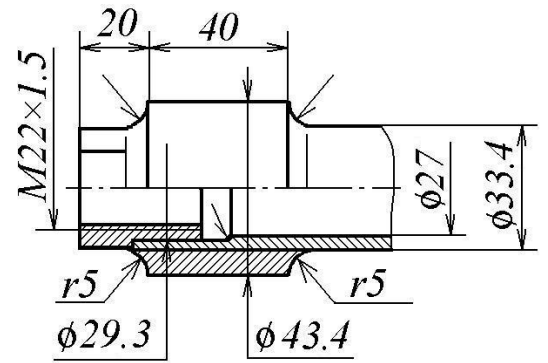

Fig. 9. Shank of connecting rod: $a$ - base version; $b$ - scheme of strengthening

The repaired connecting rod, pasted with fatigue gauges made of tin foil, successfully worked out the full season of field work and remained suitable for further exploitation. Inspection of fatigue 
gauges and analysis of their surface condition led to the conclusion that during exploitation the repaired connecting rod was exposed to uniformly distributed cyclic stresses with low amplitudes.

\section{Conclusions}

1. Fatigue gauges made of tin foil have low cost and quickly react to relatively low stresses. The described technology of application of fatigue gauges to estimate the values of the acting cyclic stresses is available to farmers and students-trainees.

2. The reliability of the parts of the mounted mower according to the monitoring results by fatigue gauges from tin foil was significantly improved. The probability of non-destruction of the knife head increased to $99.5 \%$. The assurance factor of the connecting rod after repair was increased by 2.6 times.

3. The increase of reliability and reduction of idle time of the mounted mower "KC-2,1" had a positive impact on the financial performance of the farm. Tin foil fatigue gauges are effective helpers in improving the profitability of agricultural production and attractiveness of rural areas.

\section{References}

[1] Okubo H. Determination of the surface stress by means of electroplating. Journal of Applied Physics, vol. 24, No 9, 1953, pp. 1130-1133.

[2] Окубо Х. Определение напряжений гальваническим меднением (Determination of stress by galvanic copper plating). Moscow, Mashinostroeniye Publishers, 1968. 152 p. (In Russian).

[3] Imamura Y., Sato S. Dynamic stress distribution in the helical gear measured by the copper electroplating method. Bulletin of the JSME, vol. 21, No 156, June, 1978, pp. 1038-1046.

[4] Peterson R.E. Stress concentration factors. New York, Wiley, 1974. 336 p.

[5] Fricke W.G. Fatigue gages of aluminum foil. Proceedings of the American Society for Testing and Materials, vol. 62, 1962, pp. 268-269.

[6] Сызранцев В.Н., Голофаст С.Л. Измерение циклических деформаций и прогнозирование долговечности деталей по показаниям датчиков деформаций интегрального типа (Cyclic strains measurement and machine parts longevity forecasting according to integral strain gauges indications). Novosibirsk, Nauka Publishers, 2004. 206 p. (In Russian).

[7] Syzrantsev V., Syzrantseva K. The stress-strain condition estimation of detail in crack tip by integral strain gauges. IOP Conference series: Materials Science and Engineering, vol. 127, 2016. 7 p. DOI: $10.1088 / 1757-899 X / 127 / 1 / 012051$.

[8] Syzrantsev V., Syzrantseva K. Integral strain gauges application for gearing reliability estimation. Materials Science Forum, vol. 906, 2017, pp. 44-49.

[9] Panin S.V., Burkov M.V., Lyubutin P.S. etc. Application of integral-type deformation pickups for evaluating the fatigue damage of carbon composites. Russian Journal of Nondestructive Testing, vol. 50, No 5, 2014, pp. 288-298.

[10] Syzrantseva K., Syzrantsev V. Estimation of Novikov gearing loading capacity based on integral strain gauges application. Procedia Engineering, vol. 206, 2017, pp. 1081-1086.

[11]Тютрин С.Г. Техническая диагностика металлическими покрытиями (Technical diagnostics using metal coats). Kurgan. Kurgan State University Publishers, 2007. 144 p. (In Russian).

[12] Тютрин С.Г., Сабуркин Л.Н. Модернизация головки ножа косилки КС-2,1 по результатам контроля усталостными датчиками (Modernization of the mower KC-2,1 head according to the results of fatigue gages control). Vestnik Kurganskogo gosudarstvennogo universiteta. Seriya “Tehnicheskie nauki”, 2015, № 3 (37), iss. 10, pp. 24-27. (In Russian).

[13] Weibull W. Fatigue testing and analysis of results. New York, Pergamon Press, 1961. 304 p.

[14] Forrest P.G. Fatigue of metals. London, Pergamon Press, 1970. 424 p.

[15]Тютрин С.Г., Сабуркин Л.Н. Ремонт шатуна косилки КС-2,1 по результатам контроля усталостными датчиками (Repair of connecting rod of the mower "KC-2,1" according to fatigue gauges control results). Vestnik Kurganskogo gosudarstvennogo universiteta. Seriya “Tehnicheskie nauki”, 2016, № 3 (42), iss. 11, pp. 50-54. (In Russian). 